\title{
The Impact of Internet Financial Reporting on Stock Price Performance in Egypt
}

\author{
Sara Mohamed Farouk Aggag, Heba Ali, Hassan Ouda \\ German University in Cairo
}

\begin{abstract}
As many firms recently adopt Internet financial reporting (IFR) to disclose their financial information, the impact of disclosing the financial information through the internet on stock return become one of the most important topics to investigate. The objective of this study is to examine the impact of IFR on stock price performance in Egypt. This research will help to know how the adoption of IFR affects the firm's stock return and how the quality of IFR affects the stock return and whether IFR adopting firms will have a higher abnormal stock return than IFR non-adopting firms. The findings can help stock market participants to understand the implications of IFR on the firm's stock returns.
\end{abstract}

This study examines 234 firms listed on the Egyptian stock exchange. The long run abnormal return is measured using the following two indexes EGX 100 and MSCI-Egypt. The study uses a t-test and Wilcoxon rank sum test to test the significant difference between IFR adopting firms and IFR non-adopting firms. Moreover, the study uses a multiple regression analysis to test the impact of IFR and IFRQ on abnormal stock return. The results of t-test and Wilcoxon rank sum test show significant difference between stock return of IFR adopting firms and stock return of IFR non adopting firms and significant difference between stock return high quality reporting firms and stock return of low quality reporting firms. The findings of multiple regressions reveal that IFR has a significant influence on abnormal stock return, which means that firms disclosing financial information through internet have better abnormal stock return. Also, the IFRQ has a significant influence on abnormal stock return which means that firms disclosing more financial information through internet have better abnormal stock return than firms disclosing less financial information through the internet. 
International Conference on Advanced Research in MANAGEMENT, ECONOMICS AND ACCOUNTING

5-7 September, 2019 Barcelona, spain

MFA

MANAGEMENT, ECONOMICS \& ACCOUNTING CONFERENCE

Keywords: Abnormal Return; Financial Disclosure; Internet Financial Reporting; Internet Financial Reporting Quality; Stock Price Performance. 